\title{
EXPLORING THE U-SHAPE GEOGRAPHICAL BIAS IN MANUFACTURED EXPORTS OF MERCOSUR COUNTRIES
}

\author{
Fernando Delbianco, ${ }^{a}$ Andrés Fioriti ${ }^{a}$ and Germán González ${ }^{b}$
}

Fecha de recepción: 10 de agosto de 2020. Fecha de aceptación: 15 de abril de 2021.

$$
\text { https://doi.org/10.22201/iiec.20078951e.2021.206.69731 }
$$

\begin{abstract}
We proposed a novel approach to understand the industrialization pattern of MERCOSUR countries during the last 60 years. We performed an index to measure the geographical bias of manufactured exports between the region and the world and showed that regional trade agreements allowed MERCOSUR countries to decrease the bias and increase competitiveness. However, we noted that in recent years the bias deepened in favor of exporting a higher proportion of manufactured goods to the region. Our main result is that these economies present a U-shape geographical bias in manufactured exports associated with a bimodal distribution of breaks. Furthermore, we observed that the 1980s and 2000s were the most relevant periods for defining the region trends.
\end{abstract}

Key Words: economic integration; MERCosur; industrialization; intra-industry trade; exports.

\section{EXPLORANDO EL SESGO GEOGRÁFICO U EN LAS EXPORTACIONES MANUFACTURERAS EN LOS PAÍSES DEL MERCOSUR}

Resumen. Se propone una metodología nueva para entender el patrón de industrialización en los países del MERcosur durante los últimos 60 años. Se desarrolla un índice para medir el sesgo geográfico de las exportaciones manufactureras entre esta región y el mundo, y se muestra que los acuerdos comerciales permitieron a los países del MERCOSUR reducir el sesgo e incrementar la productividad. Sin embargo, se evidencia que en ańos recientes el sesgo se ha profundizado en favor de exportar bienes manufacturados a la región. El hallazgo principal es que esas economías presentan un sesgo geográfico en forma de $\mathrm{U}$ de las exportaciones manufactureras asociado a una distribución bimodal de roturas. Más aún, se observa que las décadas de 1980 y la de 2000 fueron las más relevantes para definir las tendencias en la región.

Palabras clave: integración económica; MERCosur; industrialización; comercio intraindustrial; exportaciones.

Clasificación JEL: F1; F10; F15; F14; O14; O54.

\footnotetext{
${ }^{a}$ Universidad Nacional del Sur, Departamento de Economía e Instituto de Matemática de Bahía Blanca (INMABB)-CONICET, Argentina; ${ }^{b}$ Universidad Nacional del Sur, Departamento de Economía e Instituto de Investigaciones Económicas y Sociales del Sur (IIEss)-CONICET, Argentina. Correos electrónicos: fernando.delbianco@uns.edu.ar, andres.fioriti@uns.edu.ar and ghgonza@uns.edu.ar, respectively.
} 


\section{INTRODUCTION}

Over the years, understanding the impact of regional trade agreements (RTAS) on their members has received increasing attention. Since those agreements have been present throughout the whole world and are becoming more popular, in spite of the recent turmoil in the European Union and the apparently cyclical instability of MERCOSUR, it is important to understand whether the impact of this RTA was positive or not for involucrate semi-industrialized countries (Syrquin and Chenery, 1989).

The exploitation of economies of scale and agglomeration increases firms' productivity (Krugman, 1980; Helpman and Krugman, 1989). This reduction in the average costs represents an improvement in the sectoral competitiveness (Harberger, 1998; González, 2009) from non-spurious efforts (Fajnzylber, 1988). Moreover, Puga and Venables (1998) argued that the industrialization of a region is the expected result because of market enlargement, in the context of a South-South RTA between partners with similar economies. However, under high asymmetries and slow dismantling of regional trade resistance, the South-South preferential trade liberalization may be, on average, associated with a decreased manufacturing production in the smallest country of the agreement (Sanguinetti et al., 2009; Bekerman and Rikap, 2010). From a more traditional perspective, Venables (2003) claimed that, when partners have similar productive structures, countries with intermediate comparative advantages between them and the rest of the world benefit from the RTA, at the expense of those partners with extreme or highly concentrated advantages.

Those theoretical branches predict that semi-industrialized countries with large domestic markets experience increasing manufactured exports, principally inter-industry trade, in a South-South RTA context with initial asymmetries. However, if structural and size asymmetries do not exist, diverging patterns between countries may only be transitional because industries may start to disperse as factors of trade resistance are sufficiently reduced. In this last scenario, intra-industry trade dominates within the region. All partners experience an integration of their industries, there is a tendency to intensify their bilateral trade, and, as a corollary, an inclination to synchronize their business cycles prevails (Frankel and Rose, 1998).

At the end of the process, both cases boost extra-regional trade. The difference lies in the evolution of the specialization patterns and the distribution of the benefits between partners. While regional inter-industry trade promotes extra-regional exports supported by static comparative advantages, regional intra-industry trade drives manufactured exports to markets without 
commercial benefits. For smaller semi-industrialized economies, the first case would show a relative increase in commodity exports versus manufactured exports, with a prevalence of the flow of those goods to third markets and of the latter to the regional market. In the second case, there would be a relative increase in manufactured exports versus commodity exports, with an increasing participation of third markets in manufactured exports. However, some questions arise: is it possible for a country to experience both dynamics in a real context of integration and over a sufficiently long period? How could we identify the moment of change and the factors that determine the move from one path to another?

The main objectives of the article are to show that MERCOSUR partners have experienced both dynamics and to offer a global interpretation that combines the theoretical approaches of Puga and Venables (1998) with the new evidence. Our main result is that these economies present a U-shape geographical bias in manufactured exports associated with a bimodal distribution of breaks on the data series of their specialization patterns.

The rest of the paper is structured as follows. Section 2 presents the links between our work and the specialized literature. Section 3 explains the data, the construction of the dataset, and some descriptive statistics. Section 4 presents the break testing methodology applied and the results obtained. Section 5 compares the results with the previous literature and discusses some interpretations. Finally, section 6 presents the conclusions.

\section{LITERATURE REVIEW}

Since our paper is related to a vast literature interested in the evolution of specialization patterns of South American countries (Lo Turco, 2008; Sanguinetti et al., 2009; Bekerman and Dulcich, 2014; among others), we discussed our results in the light of some relevant papers. We focused on the destination of commodity/manufactured exports assuming that these economies have mixed productive structures and that one of their main objectives of entering into a RTA was to use the region as a platform for manufactured exports. Moreover, this target was independent of the initial level of industrialization, the relative factor endowment, and the structure and size of the domestic market. However, this starting point does not imply that we have not considered the influence that those elements may have on the industrialization process. Instead, we verified the consistency of their results by comparing them with our evidence. 
Methodologically, our approach is closer to those of Yeats (1998), Bekerman and Rikap (2010), and Durán Lima and Lo Turco (2010), since they focused on changes on the orientation of trade as a consequence of RTA. We addressed the dynamic of bilateral, regional, and extra-regional exports of MERCOSUR partners to verify that their economies could not embark on a sustainable and widespread process of industrial competitiveness gains and de-primarization of extra-regional exports. We used break determination techniques to characterize the dynamics of those series. This technique resembles the one used in Delbianco and Fioriti (2014), which attempts to capture the relationship between breaks in the external sector and the occurrence of economic crisis.

\section{MANUFACTURED EXPORTS OF MERCOSUR COUNTRIES}

MERCOSUR is an economic region consisting of asymmetric countries. In terms of area and population, Brazil tops the list with 211.4 million people distributed over 8.5 million $\mathrm{km}^{2}$. It is followed by Argentina ( 45.3 million people, 2.8 million $\mathrm{km}^{2}$ ), Venezuela (27.9 million people, 916 thousand $\left.\mathrm{km}^{2}\right)$, Paraguay (7.2 million people, 407 thousand $\mathrm{km}^{2}$ ), and Uruguay (3.5 million people, 176 thousand $\mathrm{km}^{2}$ ). However, in terms of nominal per capita income, the order for 2020 was headed by Uruguay with almost US\$ 16000 per person. Argentina follows with just over US\$8 000, Brazil with almost US\$7 000, Paraguay with almost US\$5 000, and Venezuela with US\$1 700 per person (IMF, 2021). In 2013, industrial exports as a percentage of the total exports showed a different profile between Argentina and Brazil relative to Paraguay, Uruguay, and Venezuela. While the former group was exporting above $21 \%$ of industrialized goods, the performance of the latter group was less than 13\%.

Using COMTRADE data on exports of Argentina, Brazil, Paraguay, Uruguay, and Venezuela for the 1962-2013 period, we obtained the shares of exports to each member, to the region, and to the rest of the world (meaning the whole world minus the region) of manufactured and commodity exports.

The chosen period, with over five decades of data with annual frequency, allowed us to obtain sharp test results, while considering that we used multiple specifications to increase their robustness.

Although Mercosur was born in 1991, González and Delbianco (2021) found that its deployment phase began in 1986 and extended until 1999. While the years prior to 1986 are identified as its prehistory, the 2000-2006 phase is considered as an overcoming stage in which MERCOSUR showed its 
greatest institutional development. However, the authors found that during 2007-2015 MERCOSUR returned to a commitment level equivalent to its prehistory. In order to contemplate all these stages and the possibility of different impacts on the specialization process, we considered the period starting in the early experiences of integration of the 1960s until 2013, when the five countries in question coincide in MERCOSUR.

Paraguay was suspended between June 2012 and August 2013. Moreover, it was not until December 2013 that the Congress of Paraguay ratified the Protocol of Incorporation of Venezuela into MERCosur. However, we incorporated Venezuela into the study because this country began its policy of closer ties with MERCOSUR in February 1995, being part of the MERCosur and Andean Group negotiations that concluded with the signing of the Economic Complementation Agreement No. 59 (Acuerdo de Complementación Económica, ACE 59, as per its initials in Spanish) in 2004. This agreement implied a reduction of trade barriers between the economies involved. The Andean Community, previously the Andean Pact or Andean Group, is a trade block comprising the South American countries of Bolivia, Colombia, Ecuador, and Peru, born from the signing of the Cartagena Agreement in 1969. Venezuela was part of it between 1973 and 2006.

In August 2017, Venezuela was suspended from its status of State Party of MERCosur through the application of the Ushuaia Protocol on Democratic Commitment. Moreover, Bolivia is in the process of becoming a member since 2012, so it does not qualify to be included in the study.

We adopted the 2-digit level of the Standard International Trade Classification (SITC). In order to label each group as manufacture or commodity, we used the usual definition of commodity in the trade context -which is a raw material or primary product- for identification. We differ from the usual practice of taking Sections 5 to 8 of the SITC as manufactures and the above as primary products. The main argument for this decision is that our classification is based on the final characteristics of goods, rather than concentrating on the main input used for their production. That is why vegetable and animal oils, or pulp and paper result manufactures, while iron and steel or non-ferrous metals are considered commodities.

The resulting decomposition is shown in table 1 . The distribution derives in 28 groups identified as commodities (47\%) and 32 groups identified as manufactures (53\%). 
Table 1. SITC-based classification among manufactured ${ }^{(1)}$ and commodity goods ${ }^{(0)}$

\begin{tabular}{|c|c|c|c|c|c|}
\hline $\begin{array}{l}\text { Goods } \\
\text { class }\end{array}$ & $\begin{array}{l}\text { SITC } \\
\text { 2-digit }\end{array}$ & Description & $\begin{array}{l}\text { Goods } \\
\text { class }\end{array}$ & $\begin{array}{l}\text { SITC } \\
\text { 2-digit }\end{array}$ & Description \\
\hline 0 & 0 & Live animals & 1 & 53 & Dyeing, tanning and coloring materials \\
\hline 0 & 1 & Meat and meat preparations & 1 & 54 & Medicinal and pharmaceutical products \\
\hline 0 & 2 & Dairy products and eggs & 1 & 55 & $\begin{array}{l}\text { Perfume materials, toilet and cleansing } \\
\text { preptions }\end{array}$ \\
\hline 0 & 3 & Fish and fish preparations & 1 & 56 & Fertilizers, manufactured \\
\hline 0 & 4 & Cereals and cereal preparations & 1 & 57 & Explosives and pyrotechnic products \\
\hline 0 & 5 & Fruit and vegetables & 1 & 58 & Plastic materials, etcetera \\
\hline 0 & 6 & Sugar, sugar preparations, and honey & 1 & 59 & Chemical materials and products, nes \\
\hline 0 & 7 & $\begin{array}{l}\text { Coffee, tea, cocoa, spices and } \\
\text { manufacs. thereof }\end{array}$ & 1 & 61 & $\begin{array}{l}\text { Leather, Ithr. Manufs., nes and dressed } \\
\text { fur skins }\end{array}$ \\
\hline 0 & 8 & $\begin{array}{l}\text { Feed. stuff for animals excl. unmilled } \\
\text { cereals }\end{array}$ & 1 & 62 & Rubber manufactures, nes \\
\hline 0 & 9 & Misc. food preparations & 1 & 63 & $\begin{array}{l}\text { Wood and cork manufs. excluding } \\
\text { furniture }\end{array}$ \\
\hline 1 & 11 & Beverages & 1 & 64 & $\begin{array}{l}\text { Paper, paperboard and manufactures } \\
\text { thereof }\end{array}$ \\
\hline 0 & 12 & Tobacco and tobacco manufactures & 1 & 65 & $\begin{array}{l}\text { Textile yarn, fabrics, made up articles, } \\
\text { etcetera }\end{array}$ \\
\hline 0 & 21 & Hides, skins and fur skins, undressed & 1 & 66 & Non metallic mineral manufactures, nes \\
\hline 0 & 22 & Oil seeds, oil nuts and oil kernels & 0 & 67 & Iron and steel \\
\hline 0 & 23 & $\begin{array}{l}\text { Crude rubber including synthetic and } \\
\text { reclaimed }\end{array}$ & 0 & 68 & Non ferrous metals \\
\hline 0 & 24 & Wood, lumber and cork & 1 & 69 & Manufactures of metal, nes \\
\hline 1 & 25 & Pulp and paper & 1 & 71 & Machinery, other than electric \\
\hline 0 & 26 & $\begin{array}{l}\text { Textile fibers, not manufactured, } \\
\text { and waste }\end{array}$ & 1 & 72 & $\begin{array}{l}\text { Electrical machinery, apparatus and } \\
\text { appliances }\end{array}$ \\
\hline 0 & 27 & $\begin{array}{l}\text { Crude fertilizers and crude minerals, } \\
\text { nes }\end{array}$ & 1 & 73 & Transport equipment \\
\hline 0 & 28 & Metalliferous ores and metal scrap & 1 & 81 & $\begin{array}{l}\text { Sanitary, plumbing, heating and } \\
\text { lighting fixt }\end{array}$ \\
\hline 0 & 29 & $\begin{array}{l}\text { Crude animal and vegetable } \\
\text { materials, nes }\end{array}$ & 1 & 82 & Furniture \\
\hline
\end{tabular}




\begin{tabular}{|c|c|c|c|c|c|}
\hline $\begin{array}{l}\text { Goods } \\
\text { class }\end{array}$ & $\begin{array}{c}\text { SITC } \\
\text { 2-digit }\end{array}$ & Description & $\begin{array}{c}\text { Goods } \\
\text { class }\end{array}$ & $\begin{array}{c}\text { SITC } \\
\text { 2-digit }\end{array}$ & Description \\
\hline 0 & 32 & Coal, coke and briquettes & 1 & 83 & $\begin{array}{l}\text { Travel goods, handbags and similar } \\
\text { articles }\end{array}$ \\
\hline 0 & 33 & Petroleum and petroleum products & 1 & 84 & Clothing \\
\hline 0 & 34 & Gas, natural and manufactured & 1 & 85 & Footwear \\
\hline 1 & 35 & Electric energy & 1 & 86 & $\begin{array}{l}\text { Scientif and control instrum, photogr } \\
\text { gds, clocks }\end{array}$ \\
\hline 0 & 41 & Animal oils and fats & 1 & 89 & Misc. manufactured articles, nes \\
\hline 0 & 42 & Fixed vegetable oils and fats & 0 & 93 & $\begin{array}{l}\text { Special transact. Not class. According } \\
\text { to kind }\end{array}$ \\
\hline 1 & 43 & $\begin{array}{l}\text { Animal and vegetable oils and fats, } \\
\text { processed }\end{array}$ & 0 & 94 & $\begin{array}{l}\text { Animals, nes, incl. zoo animals, dogs } \\
\text { and cats }\end{array}$ \\
\hline 1 & 51 & Chemical elements and compounds & 1 & 95 & $\begin{array}{l}\text { Firearms of war and ammunition } \\
\text { therefor }\end{array}$ \\
\hline 1 & 52 & $\begin{array}{l}\text { Crude chemicals from coal, petroleum } \\
\text { and gas }\end{array}$ & 1 & 96 & $\begin{array}{l}\text { Coin, other than gold coin, not legal } \\
\text { tender }\end{array}$ \\
\hline
\end{tabular}

Source: own elaboration.

Once all the entries were labeled as manufactures or commodities, we aggregated by country the total amount exported by year. Using the total exports of the year, we obtained the usual ratios:

$$
\text { shareofmanufacturedexport }_{i j}=\frac{\text { Amountofmanufacturedexports }_{i j}}{\text { Amountoftotalexports }_{i j}}
$$

where country $i$ is the exporter and country $j$ is the market. We calculated these ratios for each relevant destination (one for each country of MERCOSUR, one for the whole region, and one for the world minus the region).

In order to see how these series behaved in the 52-year period considered, we show below the shares of manufactured exports to the world minus the region (see figure 1) and to the region (see figure 2). The polynomial trend is added to the graphs to obtain a smoother version of the transition over time. 

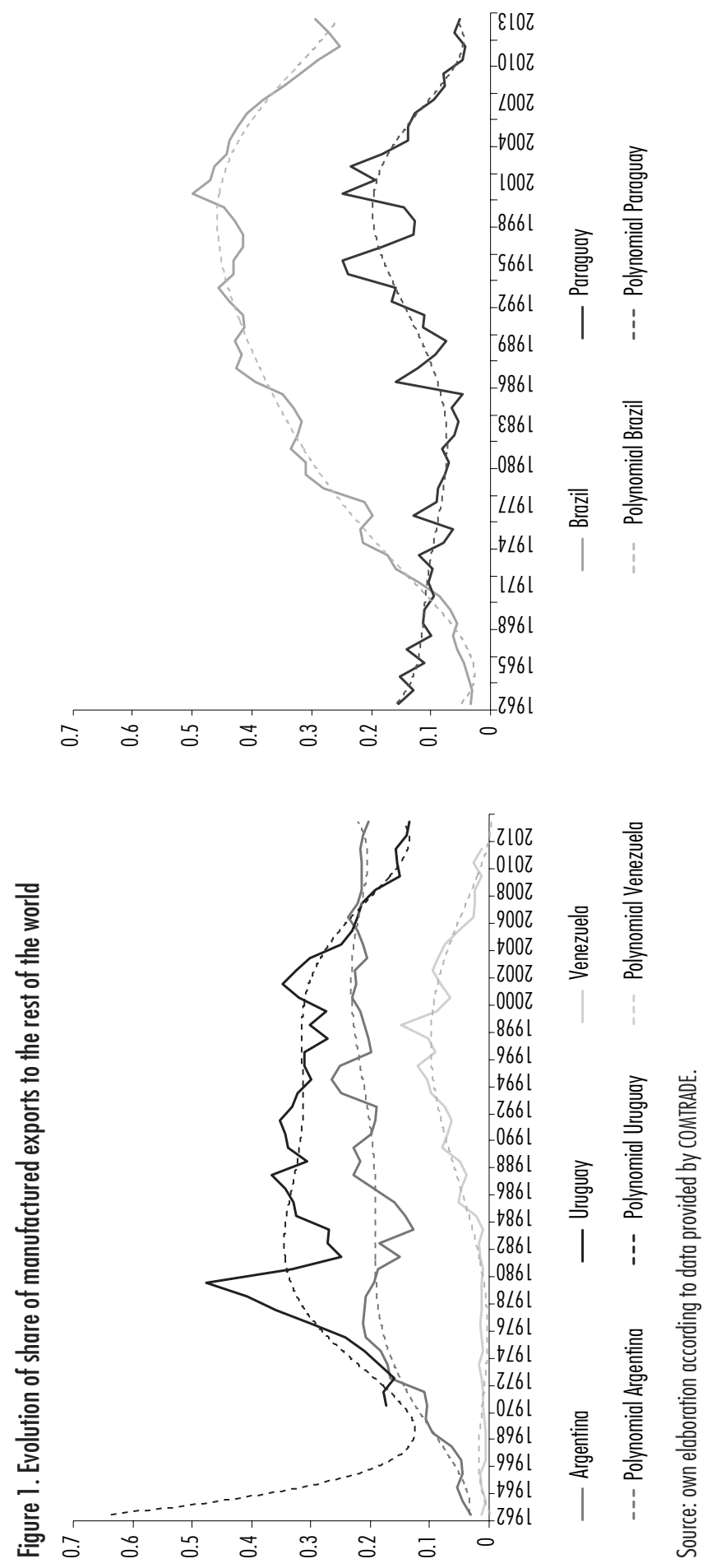

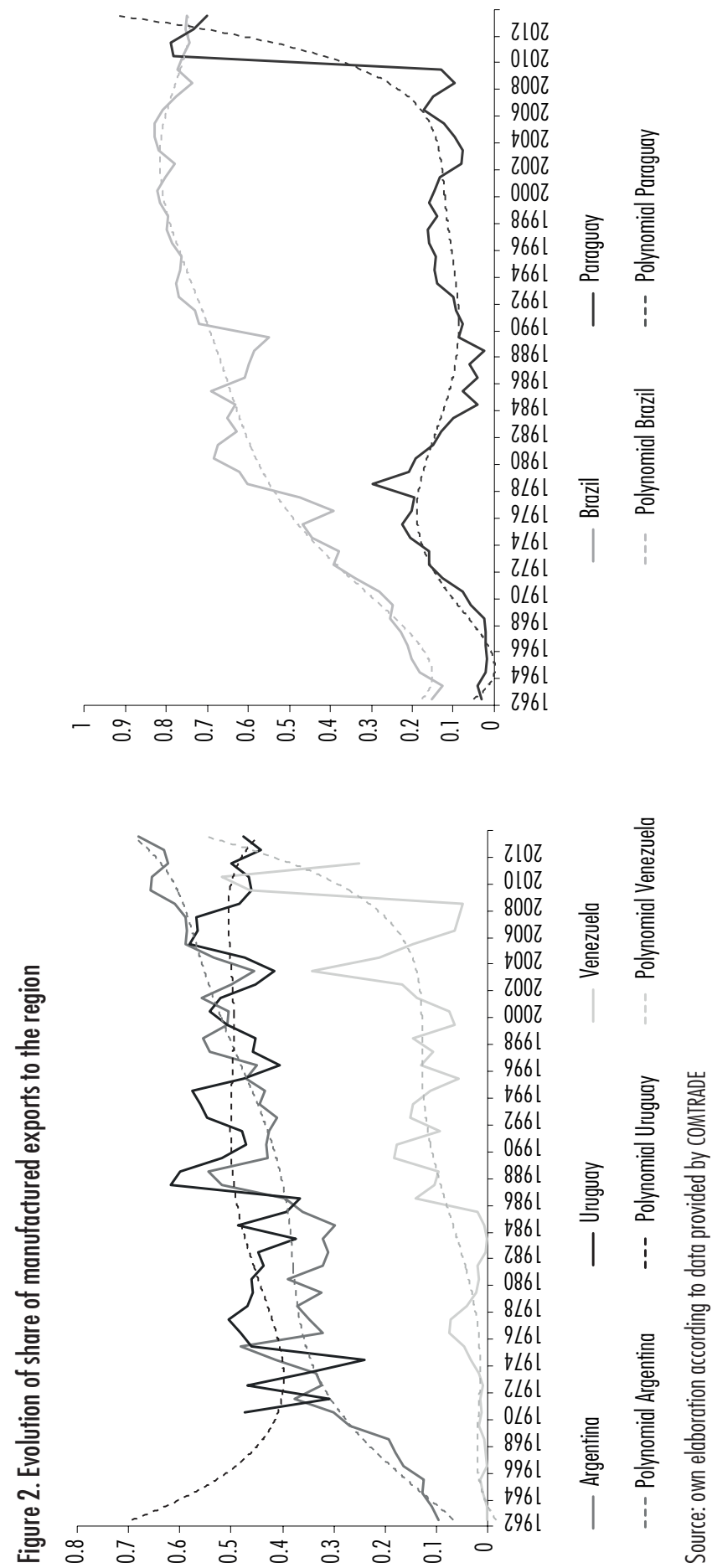
There are several facts that can be observed in the figures above. At the beginning of the sample, no country of today's MERCOSUR was exporting manufactures for a percentage greater than $20 \%$ of the total exports to the world, not even to the region. During the successive years, each country followed its own path, all of them reaching their maximum values in the world market during the 1990s, except for Uruguay, which happened previously. Argentina and Brazil leaded the de-primarization process based on exporting to the region, but Brazil showed a faster industrialization process and a better trade performance in the world market. Paraguay and Venezuela recently joined a similar path, whereas Uruguay remained rather stable while analyzing the region.

It is not particularly evident in the figure that the RTAS signed within the region fostered the industrialization of the area. We observe a positive trend in manufactured exports to the region since the 1960s in the five countries considered, while they signed some regional preferential trade and economic complementation agreements between them after the Latin American Integration Association (LAIA) in the 1980s. ${ }^{1}$ In fact, that trend is following a similar phenomenon at a world market level. Finally, in all the cases, an apparent process of primarization of exports to the world market was highlighted around the year 2000 .

Another way of considering the same issue is to observe the geographic bias of manufactured content of exports ${ }^{2}$ defined as the ratio between the share expressed in (1) for exports to the region and the same share for exports to the world markets. Thus,

Geographic bias \& manufactured content of exports ${ }_{i}=$

shareofmanufacturedexportsregion $_{i}$

shareofmanufacturedexportsworld $_{i}$

where $i$ is the exporter and the shares are calculated by following expression (1) and appropriately assigning $j$ to the region and the world market minus the region.

1 Latin American Free Trade Association (LAFTA) was the first proposal for South American economies and signed by Argentina, Brazil, Paraguay, and Uruguay in February 1960 and by Venezuela in 1970 . However, in view of the impossibility of advancing with a free-trade zone, the Treaty of Montevideo created LAIA to replace LAFTA in 1980.

2 Yeats (1998) used a more disaggregated version of this indicator, and named it regional dimension of the trade specialization process. Volpe Martincus (2003) applied a normalized version of this indicator. 
If this indicator is equal to one, it implies geographical neutrality, and this means that firms face exactly the same difficulties and challenges in exporting to the region as to the rest of the world. Therefore, the rate of manufactures exported to the region should be the same as the rate of manufactures exported to any market.

Any deviation from the neutrality assumption is reflected with a value different than one. Values higher (lower) than one represents a situation in which the ratio between manufactures and commodities exported to the region is greater (lesser) than the same ratio taking the world market as destination. In this scenario, a decreasing (increasing) trend of the bias is the result of a gain (loss) of global competitiveness because the industry is exporting relatively more (less) manufactures to markets without access facilities or with greater possibilities of substitution.

Figure 3 highlights a similar geographical bias behavior for Argentina, Brazil and Uruguay. All three cases show values above one and follow a U-shape path marking a period of relative expansion of manufactures since the end of the 1960s and, after an apparent stagnation during the 1990s, followed by a decline to initial values from 2000 onwards. In contrast, Paraguay and Venezuela seem to respond to different dynamics than their partners. Although at times they presented some values below one, Venezuela showed a bias in favor of the region for over $70 \%$ of the years, while Paraguay has done so for $50 \%$ of the years. The geographical bias indicator took values above 10 from 2010 to 2013 for Paraguay and above 19 from 2009 to 2011 for Venezuela.

The Paraguayan economy has always concentrated its activities on the production of primary goods and, mainly, on agriculture. An important exception to this trend was the period of construction of the Paraguayan-Brazilian Itaipú dam in the 1970s (Richards, 2011) and the significant increase in exports of beef products and soybean oil, with Venezuela being one of its main markets after 2004 (Swanson, 2012).

The evolution of the Venezuelan bias is associated with the evolution of petroleum exports and their price. Di John (2009) stated that, while the period 1920-1965 is characterized by a positive correlation between the growth of non-petroleum sectors and the real crude oil price, the subsequent period 1965-1998 is marked by a significantly negative relationship between these two variables. That evidence prevents a full explanation of the industry performance based on the Dutch disease scheme. In any case, this scheme allows us to observe the expansion period of the years 1980s and 1990s in a reasonable way. The devaluations of those years and the depression of the domestic economy helped boost industrial exports, but when the overvaluation of the 
bolivar worsened, serious problems of productivity and setbacks in the rate of industrial growth were noted (Hernández and Villalobos, 1997).

In terms of the peaks observed in the indicator, periods of high growth of the crude oil price resulted in greater values for its exports, mainly to third countries. The denominator of formula (2) is decreasing, and so is the numerator, although to a lesser extent. This combination derives in an overestimation of the bias in the manufacturing content of exports to the region. The similarity between the figure of the bias in the manufacturing content of Venezuelan exports and the evolution of the real price of the barrel of crude oil during the period considered is noteworthy.

It is interesting to note that the contemporaneity of periods of rising values in the partners' indicator -as in the figure for Argentina, Brazil, and Uruguaycould represent more regional complementarity in industrial goods and the strengthening of the economic bases for regionalization. However, the other side of the same process is the likely primarization of exports for the global market. This means that, while manufactures were oriented to the partners' economies, countries maintained their position as suppliers of raw materials and other commodities to the world.

Moreover, these figures show that, contrary to what would be expected, the process of intensifying regionalism does not appear to have generated a sharp increment in the geographical bias of manufactured exports. The period of highest growth in intra-regional trade -in particular intra-industry tradecoincides with the period of lower values of the index. Between 1990 and 1999, the four founder members -Argentina, Brazil, Paraguay, and Uruguaysignificantly increased their Grubel-Lloyd index ${ }^{3}$ among them, but also with the rest of the world (Kim and Lee, 2003).

During the Commodities Boom, that is the period 2000-2011 -except for a sharp down-turn in prices during 2008 and early 2009-, the figures of MERCosur's economies -excluding Brazil- shown an increment of manufactured exports to the region and a rising share of commodity exports -except for Argentina. Graphically, the correspondence between both trends is displayed in figure 3 as the upward part of the curves.

Results show an overall behavior consistent with the first scenario presented in the Introduction. This means that the integration process helped sustain the demand for manufactured products in a context of growing globalization. However, the advantage of market access guaranteed by MERCOSUR was not

This index is a widely used measure of the importance of intra-industry trade. By construction, the Grubel-Lloyd index ranges between zero and one, indicating the absence of intra-industry trade if the index take zero value. 


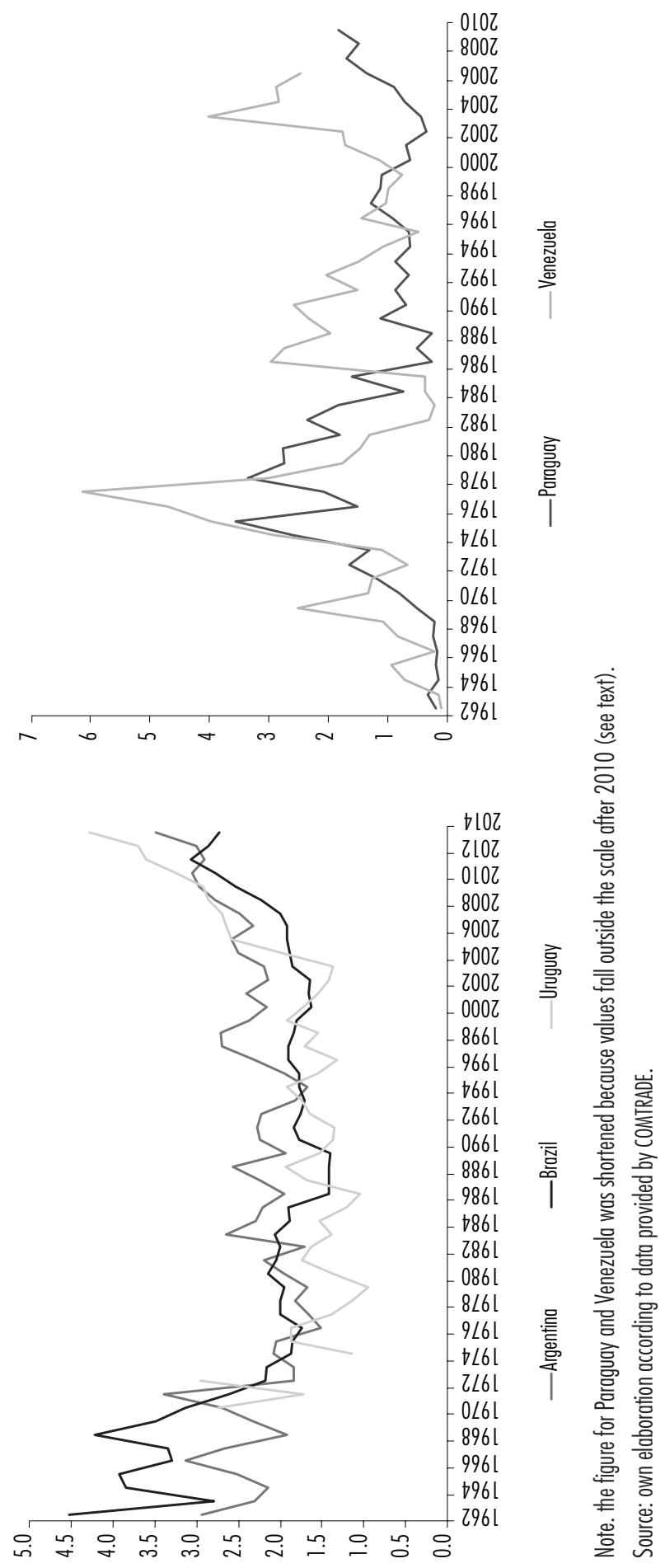


possible to materialize into gains in global competitiveness that would lead to a persistent change in the profile of these countries in the world market.

The research presented below has sought to verify the existence of breaks in the specialization paths that give statistical support to the U-shape of the geographical bias of manufactured exports. The identification of the break points on the time series will reduce the difficulty associated with establishing the determinants of that phenomenon.

\section{BREAKS TESTING AND RESULTS}

\section{Zivot and Andrews (ZA) (1992)}

The classic augmented Dickey-Fuller (1984) test (ADF) with three different specifications (with trend, with constant, whit drift) without structural changes in the series analyzed generally shows that the series are non-stationary. However, this result is not surprising when working with relatively long time series. A different approach is followed in the work of Zivot and Andrews (1992), which endogenously determines the date of structural change.

The zA test sequentially analyzes the possible presence of structural changes in the series in each observation, generating dummies in each period. A dummy with a higher level of significance is considered to indicate the period in which the series under study undergoes a change of regime. By removing these sequentially incorporated dummies, the zA test takes then the classic format of a stationarity test (a test of unit root) like the ADF.

$\mathrm{ZA}$ is not a structural break test per se. It is, as mentioned, a way to make a stationarity test which tests the null hypothesis of a unit root against the alternative hypothesis of stationarity with a break point at some unknown point in the series.

Therefore, this test has the characteristics of a unit root test with a notation similar to that of Perron (1989), but without defining the structural break endogenously. The null hypothesis that ZA poses for the three models is:

$$
y_{t}=\mu+y_{t-1}+e_{t}
$$

Thus, it is considered that, under $H 0$, the series is integrated without structural changes. Then, the selection of $\lambda$ is the result of the search for a dummy that achieves a stationary representation of $y_{t}$. This means that the alternative hypothesis implies stationarity with a single break. The objective is then to 
estimate the break (the dummy) that most weights the alternative of stationarity.

$\lambda$ is chosen to minimize the one-tail t-statistic, testing that $\alpha^{i}=1$ for $i=A, B, C$, since small values of the statistic denote rejection of the null. In other terms,

$$
t_{\widehat{\alpha}^{i}}\left[\hat{\lambda}_{\text {inf }}^{i}\right]=\inf _{\lambda \in \Lambda} t_{\alpha^{i}}
$$

where $\Lambda \in(0,1)$.

As now, the null is specified as in equation (3). Then, the equations for return in ZA unit root test are:

$$
\begin{aligned}
y_{t}= & \hat{\mu}^{A}+\hat{\theta}^{A} D U_{t}(\hat{\lambda})+\hat{\beta}^{A}+\hat{\alpha}^{A} y_{t-1}+\sum_{j=1}^{k} \hat{C}_{j A} y_{t-j}+\hat{e}_{t} \\
y_{t}= & \hat{\mu}^{B}+\hat{\gamma}^{B} D T_{t}(\hat{\lambda})+\hat{\beta}^{B} t+\hat{\alpha}^{B} y_{t-1}+\sum_{j=1}^{k} \hat{C}_{j}^{B} \Delta y_{t-1}+\hat{e}_{t} \\
y_{t}= & \hat{\mu}^{C}+\hat{\theta}^{C} D U_{t}(\hat{\lambda})+\hat{\gamma}^{C} D T_{t}(\hat{\lambda})+\hat{\beta}^{C} t+\hat{\alpha}^{C} y_{t-1}+ \\
& \sum_{j=1}^{k} \hat{C}_{j}^{C} \Delta y_{t-1}+\hat{e}_{t}
\end{aligned}
$$

where $D U_{t}(\hat{\lambda})=1$ if $t>T \lambda, 0$ otherwise; $D T_{t}(\hat{\lambda})=t-T \lambda$ if $t>T \lambda$, 0 in any other case. $\hat{\lambda}$ is the estimated break point after the mentioned procedure.

For each $\lambda$, the number of $k$ extra lags were determined using Perron's procedure. Then, the t-statistic was computed. The minimum $t$ obtained on T-2 regressions indicates then the estimated break date.

Once the selection of $\lambda$ is no longer exogenous through the estimation method, zA can no longer use the critical values computed by Perron's test. Now $H 0$ is rejected if:

$$
\inf _{\lambda \in \Lambda} t_{\alpha} i(\lambda)>k_{\text {inf } \alpha}^{i}, \quad i=A, B, C
$$


with $k_{\text {inf } \alpha}^{i}$ as the critical size $\alpha$ (toward the left tail of the distribution of the statistic) of the asymptotic distribution of $i n f_{\lambda \in \Lambda} t_{\alpha} i(\lambda)$. Here, zA claims that, by definition, these critical values are, at least, as large as those obtained under an exogenous $\lambda$. From this perspective, then, the unit root test of Perron would be biased to reject the null hypothesis.

\section{Clemente, Montañes, and Reyes (1998)}

A particular extension of the test proposed by Perron and Vogelsang (1992) can be found in Clemente et al. (1998), for the case of two structural breaks. While the authors recognized that the introduction of a two-breaks test was due to Lumsdaine and Papell (1997), this modification was thought for breaks in the trend. Thus, Clemente et al. (1998) performed an application to the case of two beaks in the trend.

The null hypothesis of this test is:

$$
H 0: y_{t}=y_{t-1}+\delta_{1} D T B_{1, t}+\delta_{2} D T B_{2, t}+\mu_{t}
$$

while the alternative hypothesis has the following shape:

$$
H 1: y_{t}=\mu+d_{1} D U_{1, t}+d_{2} D U_{2, t}+e_{t}
$$

where $D T B_{i, t}$ is a variable that takes value 1 if $t=T B_{i}+1(i=1,2)$, otherwise it is zero; while $D U_{i, t}=1$ if $t>T B_{i}(i=1,2)$, and zero otherwise. The periods in time that the breaks take place are denoted as $\mathrm{TB}_{1}$ and $\mathrm{TB}_{2}$, representing the two breaks. The authors assumed that the shape of the breaks is $T B_{i}=\lambda_{i} T(i=1,2)$ with $\lambda_{i}$ between 0 and 1 , and $\lambda_{2}>\lambda_{1}$.

Moreover, two different specifications are introduced, additive outliers (AO) and innovational outliers (IO). For the latter, the functional form of the unit root that is tested is:

$$
\begin{aligned}
y_{t}= & \mu+\rho y_{t-1}+\delta_{1} D T B_{1, t}+\delta_{2} D T B_{2, t}+d_{1} D U_{1, t}+d_{2} D U_{2, t}+ \\
& \sum_{i=1}^{k} c_{i} \Delta y_{t-1}+e_{t}
\end{aligned}
$$


The method used for the test is by minimizing the value of a pseudo $t$ ratio.

For the case of AO, the model that is tested is similar, but without the deterministic component:

$$
y_{t}=\mu+d_{1} D U_{1, t}+d_{2} D U_{2, t}+\hat{y}_{t}
$$

and the test for $\rho$ is conducted under:

$$
\begin{aligned}
\hat{y}_{t}= & \sum_{i=0}^{k} \psi_{1, i} D T B_{1, t-i}+\sum_{i=0}^{k} \psi_{2, i} D T B_{2, t-i}+\rho \hat{y}_{t-1}+ \\
& \sum_{i=1}^{k} c_{i} \Delta y_{t-1}+e_{t}
\end{aligned}
$$

\section{Results}

We provided different specifications and tests to avoid issues relative to the sensitivity of the chosen method. For example, one test can claim that there was a break because of a level difference, while another can characterize a trend break, being both possible. The sum of the results evidences a break in the considered year.

Table 2 presents the results distinguishing by origin, destination, and identification technique, where World (-R) refers to the exports from the origin to the whole world minus the region and the rest of the legends are straight-

\begin{tabular}{|c|c|c|c|c|c|c|}
\hline Origin destination & DF & $Z A I$ & ZA T & $Z A I+T$ & Clem 10 & Clem AO \\
\hline \multicolumn{7}{|l|}{ Argentina } \\
\hline Brazil & ns & 1976 & 2005 & 1976 & 1981s, 2003s, ns & $1984 \mathrm{~s}, 2005 \mathrm{~s}$, ns \\
\hline Paraguay & ns & 1981 & 1970 & $1981^{\star}$ & $1966 s, 1979 s, s$ & 1982s, 1988s, ns \\
\hline Uruguay & ns & $1970^{\star}$ & $1971^{\star \star}$ & $1979^{\star \star *}$ & $1967 \mathrm{~ns}, 1973 \mathrm{~s}, \mathrm{~ns}$ & $1966 \mathrm{~s}, 2001 \mathrm{~s}, \mathrm{~s}$ \\
\hline Venezuela & $s^{\star}$ & $2000^{*}$ & 1993 & 1976 & $1974 s, 1998 s, n s$ & $1973 \mathrm{~ns}, 2000 \mathrm{~s}$, ns \\
\hline World (-R) & ns & 1972 & 1974 & 1972 & 1970 s, 1982s, ns & $1973 \mathrm{~s}, 1981 \mathrm{~ns}, \mathrm{~ns}$ \\
\hline Region & ns & 1981 & 1971 & $1976^{\star}$ & 1983s, 2002s, ns & 1988s, 2006s, ns \\
\hline
\end{tabular}
forward.

Table 2. Break years by origin, destination, and identification technique 
Table 2. Break years by origin, destination, and identification technique (continuation)

\begin{tabular}{|c|c|c|c|c|c|c|}
\hline Origin destination & $D F$ & ZAI & ZAT & $Z A I+T$ & Clem 10 & Clem AO \\
\hline \multicolumn{7}{|l|}{ Brazil } \\
\hline Argentina & ns & 1977 & 1997 & 1990 & $1975 s, 1988 s, s$ & 1978s, 1991s, ns \\
\hline Paraguay & $s^{\star \star}$ & 2005 & 1976 & 1983 & $1966 n s, 1985 s, s$ & $1965 \mathrm{~s}, 1984 \mathrm{~s}, \mathrm{~ns}$ \\
\hline Uruguay & ns & $1978^{\star}$ & 1991 & $1978^{\star}$ & $1968 s, 1977 s, s$ & $1976 \mathrm{~s}, 1987 \mathrm{~s}, \mathrm{~ns}$ \\
\hline Venezuela & $s^{\star \star}$ & 1992 & $2005^{\star}$ & $1999^{*}$ & 1988s, 2006s, ns & $1994 \mathrm{~s}, 2007 \mathrm{~s}, \mathrm{~s}$ \\
\hline World (-R) & ns & 2001 & 1993 & 1992 & $1976 s, 2006 s, n s$ & 1975 s, 1987s, ns \\
\hline Region & ns & 1977 & 1981 & 1977 & 1976 ns, 1988s, s & 1974s, 1991s, ns \\
\hline \multicolumn{7}{|l|}{ Paraguay } \\
\hline Argentina & ns & $1984^{\star \star}$ & $1991^{\star *}$ & $1986^{\star \star}$ & $1969 \mathrm{~ns}, 1993 \mathrm{~s}$, ns & 1993s, 2007s, ns \\
\hline Brazil & ns & 1980 & 2004 & 1980 & $1978 s, 2008 s, s$ & 1980s, 2007s, ns \\
\hline Uruguay & ns & 2000 & 1997 & 2000 & $1991 s, 1998 s, s$ & 1990 s, 1997s, s \\
\hline Venezuela & $s^{* *}$ & $1972^{*}$ & $1990^{* *}$ & $1971^{* *}$ & $1966 \mathrm{~s}, 1976 \mathrm{~s}, \mathrm{~s}$ & $1965 \mathrm{~s}, 1984 \mathrm{~s}, \mathrm{~ns}$ \\
\hline World (-R) & ns & 1986 & 2003 & 1992 & 1990 s, 2005s, ns & 1991s, 2005s, ns \\
\hline Region & ns & 1981 & 2005 & 2005 & $1997 \mathrm{~ns}, 2008 \mathrm{~s}, \mathrm{~s}$ & 1970 s, 2007s, ns \\
\hline \multicolumn{7}{|l|}{ Uruguay } \\
\hline Argentina & $s^{\star \star}$ & $1981^{\star}$ & $2005^{\star \star}$ & $1979^{*}$ & $1973 \mathrm{~s}, 1982 \mathrm{~ns}, \mathrm{~s}$ & 1972s,1981ns, ns \\
\hline Brazil & $s^{\star \star}$ & $1987^{\star \star}$ & 1989 & $1987^{\star \star}$ & $1972 \mathrm{~ns}, 1985 \mathrm{~s}, \mathrm{~s}$ & $1980 \mathrm{~ns}, 1984 \mathrm{~s}, \mathrm{~ns}$ \\
\hline Paraguay & ns & 1995 & 2000 & 1995 & $1994 s, 2001 s$, ns & $1996 s, 2004 s, n s$ \\
\hline Venezuela & $s^{\star \star}$ & $1995^{\star \star}$ & $1978^{\star \star}$ & $1983^{\star \star}$ & $1984 n s, 1993 s, s$ & 1980ns, 1992s, s \\
\hline World (-R) & ns & 2004 & 1978 & 1980 & $1974 s, 2002 s, n s$ & 1977s, 2005s, ns \\
\hline Region & $s^{\star \star}$ & $1987^{\star \star}$ & $1989 * \star$ & $1987^{\star \star}$ & $1973 \mathrm{~ns}, 1985 \mathrm{~s}, \mathrm{~s}$ & $1972 \mathrm{~ns}, 1983 \mathrm{~s}, \mathrm{~ns}$ \\
\hline \multicolumn{7}{|l|}{ Venezuela } \\
\hline Argentina & ns & $1994^{*}$ & $2000^{\star *}$ & $1995^{\star}$ & $1982 s, 1998 s$, ns & $1981 s, 2003 \mathrm{~s}, \mathrm{~ns}$ \\
\hline Brazil & $s^{\star \star}$ & 2003 & $2001^{\star \star}$ & 1999* & $1986 s, 2005 s, s$ & $1986 s, 2004 s, s$ \\
\hline Paraguay & $s^{*}$ & 1993 & $1969^{*}$ & 1993 & $1966 \mathrm{~s}, 1991 \mathrm{~s}, \mathrm{~s}$ & $1965 \mathrm{~s}, 1990 \mathrm{~s}, \mathrm{~ns}$ \\
\hline Uruguay & ns & $2003^{\star}$ & $2001^{\star}$ & $1991^{*}$ & 1982s, $2001 \mathrm{~s}, \mathrm{~ns}$ & 1981s, 2004s, ns \\
\hline World (-R) & $s^{\star \star}$ & $2004^{\star \star}$ & $1980^{\star \star}$ & $2004^{\star \star}$ & $1988 \mathrm{~s}, 2005 \mathrm{~s}, \mathrm{~ns}$ & $1986 n s, 2005 n s, n s$ \\
\hline Region & $s^{\star \star}$ & 2003 & $2002^{*}$ & 1999 & $1985 s, 2005 s, n s$ & $1985 \mathrm{~s}, 2004 \mathrm{~s}, \mathrm{~ns}$ \\
\hline
\end{tabular}

Notes: s: significant; ns: non-significant; ${ }^{\star}$ and ${ }^{\star \star}$ : 5 and $1 \%$ level of significance, respectively; (-R): minus Region; DF: DickeyFuller; ZA: Zivot-Andrews; Clem: Clemente; 10 and A0: Innovative and Additive Outliers. Exports flows between Paraguay and Venezuela have several missing data that generates breaks, phenomenon that not strictly relates to reality (these breaks are highlighted in bold).

Source: own elaboration. 
There are several facts that we observed in table 2 and mainly in figures 4 and 5. In the one hand, only three years between 1965 and 2008 show no break in the share of manufactured exports among current MERCOSUR countries (1967, 1989, and 2002). The accumulation of statistically significant breaks marks a distribution with greater concentration between the 1980s (19 breaks) and the 1990s (20 breaks). However, the first of these decades is the only one that has a year with perfect contemporaneity in breaks in four partners. Just like the year 1984, only 2005 presents perfect contemporaneity between, at least, four economies.

On the other hand, the periods of higher frequency of breaks in exports to a partner are consistent with the periods of higher frequency of breaks in exports to the region in aggregate terms. While this may seem obvious, it is usually the case that a sudden decline in exports to one destination may be offset by higher exports to another destination within the region. Therefore, data may be showing several breaks in the manufacturing content of exports to different destinations and no change in the manufacturing content of exports to the region. This explains why the number of breaks in figure 4 is significantly higher than the number of breaks in figure 5. However, the mid-1980s, again, and the mid-2000s appear to be significant moments in the evolution of the specialization pattern of those economies.

Another observation that emerges from figure 5 is that the distribution of breaks in the manufacturing content of exports to the region is similar to that observed in the same series to the rest of the world. Although there is no perfect contemporaneity, the figure shows the greatest concentration in the mid1980s and in the mid-2000s. In 2005, three MERCOSUR partners experienced breaks in their shares of manufactured exports to the world.

Finally, the previous observations describe a series of cumulative breaks with a bimodal distribution whose peaks in the mid-1980s and mid-2000s match with the beginning and the end, respectively, of the lowest segment of the U-shape series of the geographical bias of manufactured exports. 


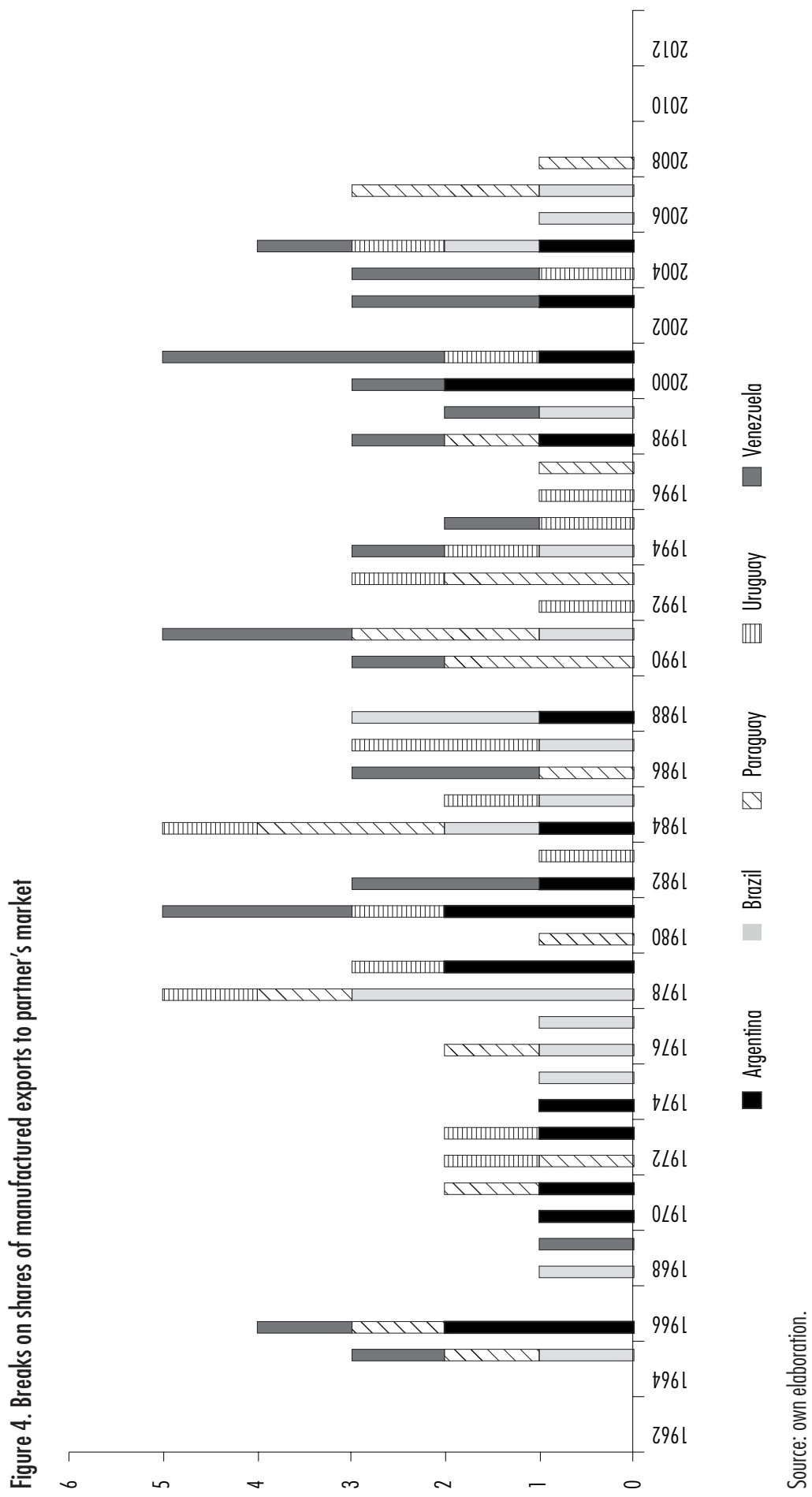


Figure 5. Accumulation of breaks on shares of manufactured exports to the region and to the world market

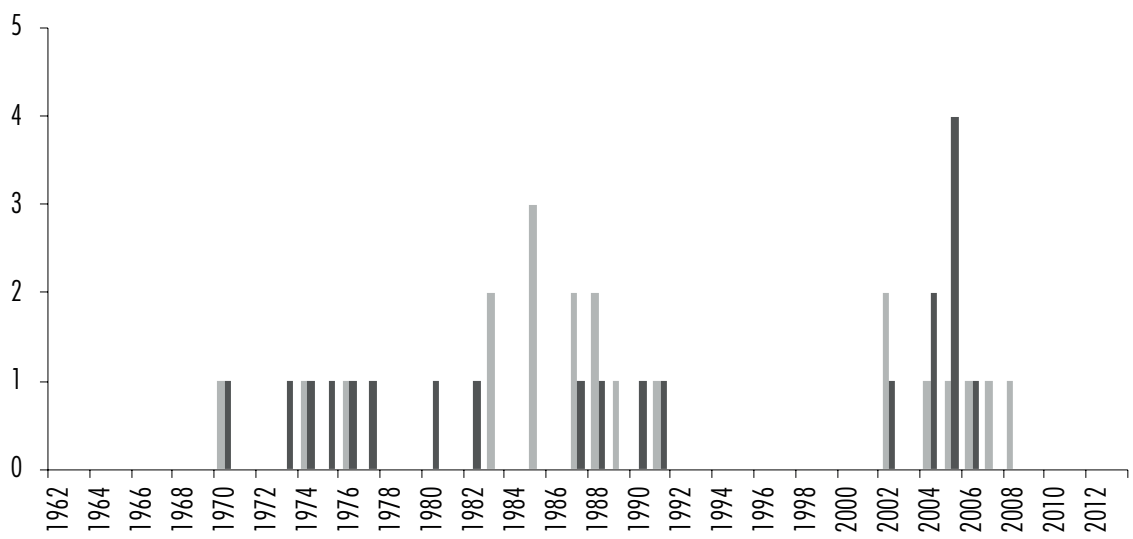

All breaks with region

- All breaks with world market

Source: own elaboration.

\section{DISCUSSION}

Both peaks of the series of cumulative breaks coincide with two critical moments of MERCOSUR, according to the k-means periodization proposed in González and Delbianco (2021). As reported by these authors, the first one closes the MERCOSUR's prehistory and gives place to the deployment phase (1986-1999), and the second one opens a regressive transformation process (2007-2015). Based on the Kojima index of trade intensity, Cordero and González (2018) showed that while the deployment phase identifies a favorable trend to regional trade in detriment of extra-regional trade, all the partners reversed that trend beginning within a time window that runs from 2000 to 2004.

The "flat" segment of the curve of the geographical bias in manufactured exports, whose limits are given by the peaks in the series of cumulative breaks, is consistent with a contemporary increase in intra-industry trade between MERCOSUR partners and between them and the rest of the world. Kim and Lee (2003) claimed that intra-industrial trade grew drastically after the establishment of MERCOSUR, but this result not only covers regional trade, but also world trade between 1992 and 1999. For their part, Fullerton et al. (2011) remarked the high 2003 values of the Grubel-Lloyd index for Argentine and 
Brazilian trade with the world market, and showed values close to the world average for Uruguay and Venezuela.

In the case of Argentina, De Cicco et al. (2013) verified the correspondence between the global and regional Grubel-Lloyd index for the period 1992-2007. However, they showed that the global index was relatively stable between 1997 and 2007 at 35\% of its total trade, while it has increasing values over $45 \%$ for the regional one, driven mainly by the Argentina-Brazil integration of the automotive sector.

Early on, Yeats (1998) noted that, between 1988 and 1994, MERCOSUR became less internationally competitive in products where trade was reorienting most rapidly towards the region. The Balassa index of revealed comparative advantage for MERCOSUR countries declined for the products that were growing the fastest in regional trade. However, more than twenty years later, our evidence implies a positive evaluation of the regionalization process where these semi-industrialized countries develop technological capacities and economies of scale, describing an emerging change of their export profile.

Bekerman and Rikap (2010) argued that the results obtained by Yeats (1998) contradict the late reality. Through learning processes, MERCosur allowed to increase trade with countries outside the block, mainly for Brazil and in a lesser extent for the other members. Kim and Lee (2003) provided evidence in accordance with this interpretation. They found that products with high Grubel-Lloyd index values for Argentina and Brazil were mostly in the sectors of chemicals, manufactured goods, and machines and transportation equipment, which are sectors with economies of scale. Fullerton et al. (2011) reached the same results for the year 2003. However, this is not the case of Paraguay, whose principal sectors were food and live animals, and crude materials, according to Kim and Lee (2003), or beverages and tobacco, and animal and vegetable oils, as reported by Fullerton. In 2003, Uruguay showed relative high values of the index in beverages and tobacco, and chemical and related products, while Venezuela did it in beverages and tobacco, chemical products, and manufactured goods classified by materials.

While Lo Turco (2008) argued that MERCOSUR became a very important destination for exports of medium- and low-technology industrial goods in the period 1985-1999, natural resources-based goods also grew in relevance. Therefore, the structure of regional exports changed slightly in favor of highand medium-technology industrial goods between 1985 and 2004. By using a regional variant of the Balassa index, this author showed that Brazil maintained its leadership as exporter of industrial goods throughout the period 1985-2004, being the only one of the partners with positive indicator va- 
lues. Argentina, on the other hand, improved its position in high-technology industrial goods, but showing regional comparative disadvantages. Similarly, Paraguay revealed a loss of comparative advantage in natural resource-based industrial goods and an improvement in medium- and low-technology industrial goods. Uruguay, instead, improved its role as a supplier of natural resource-based manufactures, but also enhanced its profile in high- and medium-technology manufactures.

Lo Turco (2008) found that there was a polarization of the productive specialization between Brazil and the smallest MERCosur partners, with only a few exceptions in certain sectors and products, and an intermediate position of specialization in the Argentinean case. On the one hand, despite the increasing regional intra-industry trade during this period, regional integration has strengthened the comparative advantages of resource-rich countries, reflected in the industrial production and exports mostly based on the exploitation of natural resources. On the other hand, the same process of integration has favored the forces of agglomeration by making Brazil a beneficiary for increased specialization in industrial activities that are intensive of skilled labor. Moncarz et al. (2016) reached a similar conclusion. However, they emphasized that these results do not mean that MERCOSUR may have contributed to Brazil's industrialization objective at the expense of the smallest partners, since these countries have also benefited from the access to the far larger Brazilian market.

Bekerman and Rikap (2010) concluded that, during the following ten years after the publication of Yeats's analysis, MERCosur proved to be beneficial to expand trade with third countries and diversify it in the medium and long term based on an interesting process of capacities development. Lucángeli (2007) presented a similar assessment after verifying the increasing two-way trade in chemicals between Argentina and Brazil. Although our results neither contradict theirs nor support Yeats, we are able to suggest that there will be a setback at the end of the long period under consideration. In fact, Bekerman and Dulcich (2014) remarked the increasing Argentinean dependence on Brazilian imports -principally the automotive, plastic and auto parts industry-, and their results confirm the specialization patterns described by Lo Turco (2008). Volpe Martincus (2003), for his part, used the index of regional dimension of the trade specialization process to observe an increasing geographical disparity in trade patterns across sectors. Export orientation towards MERCOSUR, relative to the rest of the world, has increased in those sectors which are favored by public policies (automotive) and in those sectors in 
which there is a regional comparative advantage (tobacco) or less comparative disadvantage (textiles and wearing apparel).

Similar results were presented by Reig Lorenzi and Puchet Anyul (2019) and Corbella and Sarmento (2017) using a systemic measure of integration in an input-output framework. The first paper shows that productive integration has been declining since mid-2000s, and the authors emphasized that such behavior was based on the degree of integration between Brazil and Argentina, while Uruguay followed a similar pattern, but maintaining a marginal trade relationship with its bigger partners. The second paper presents the remarkable reduction of productive integration in 2005 with respect to 1995 . However, the degree of integration of exports of capital goods and of intermediate parts and components has been increasing since 2005. This means a growing dependence -despite the low intensity of productive integration- on the regional market for the exports of these types of goods.

Gayá and Michalczewsky (2014) observed that during 2003-2011 there was an expansion phase of South American exports. In addition, regional sales developed at a higher average rate than shipments to the rest of the world did. In particular, the best performance of intra-zone trade was observed between 2004 and 2008. According to the authors, the prevailing model of international insertion was the one theorized by Venables (2003), which predicts inter-industrial trade based on comparative advantages with the rest of the world and significant intra-industrial regional trade. This remark was valid even for Brazil -the most industrialized country in the region-, but with a trend towards the primarization of its exports. They calculated that, during 2003-2011, the average intra-industrial trade between Argentina-Brazil, Argentina-Uruguay, Brazil-Uruguay, and Uruguay-Paraguay exceeded 28\% of the total trade -all these trades except the last one have a steady or increasing trend. The intra-industrial trade between Argentina and Paraguay, and Brazil and Paraguay averaged 15 and 10\%, respectively. On the other hand, Venezuela showed very low percentages as expected.

Based on the information provided by the specialized literature and the evidence generated from our study, we are able to offer a synthesis, which, at least is a well-supported conjecture. It requires empirical comparison using appropriate techniques, but presents reasonable evidence in its favor. Considering the dynamics of intra-industrial, regional, and global trade, and the series of cumulative breaks with a bimodal distribution, it is possible to develop a unified interpretation of the U-shape of the geographical bias in the manufactured content of exports. 
The 1980s saw the exhaustion of the industrial sector that grew during the previous decades under state protection. Over the 1990s, the open regionalism and the plan of structural reforms allowed a productive reconversion, but the continuing own and neighboring crises did not facilitate this process. Two competing forces diverged during those years. The first one was supported by a productive sector based on static comparative advantages, homogeneous products, and which is reasonably detached from the economic and political context and its volatility. The latter was sustained by a sector dependent on the development of new technological capabilities - a necessary condition for winning markets-, benefited from preferential trade agreements and the remnants of the industrial policy of previous decades. While external conditions were favorable, manufactured exports were relevant and the second path succeeded in approaching the first. In the early 2000s, these economies surrendered to the great markets' demand for commodities (Delbianco and Fioriti, 2018 and 2019). The industrial sector could survive due to the domestic market, the MERCOSUR trade policy, and some competitive corrections to the real exchange rate.

Bekerman and Rodríguez (2005) argued that the harmonization of macroeconomic (especially exchange rate policies) and microeconomic policies, as well as the creation of supranational institutional instances with suitable levels of enforcement, are essential to obtain successful processes of integration. When considering Mercosur, none of these conditions are met and several abrupt changes in relative prices have affected such harmonization, giving rise to commercial conflicts, reducing regional trade, and increasing the costs of industrialization by protected regional market (in the sense of Cooper and Massell, 1965). As postulated by the theory, the reduction of asymmetries and the prompt dismantling of trade resistance appear to be essential to generate the conditions for the development of intra-industry trade and the competitiveness gains for all partners, and an even distribution of the costs of trade diversion (Moncarz et al., 2016). 


\section{CONCLUDING REMARKS}

We addressed the problem of industry development during the intensification of regionalism in South America, in particular, MERCOSUR. The research focused on trade performance and, particularly, on the orientation of manufactured exports as an indicator of the evolution of the industry, according to intra-industrial trade models. The new evidence has been confronted with an abundant literature on the evolution of specialization patterns in the economies covered.

The main result has been the identification of a U-shaped bias in the manufacturing content of exports. It is possible to explain that bias through a well-supported conjecture based on the theory of intra-industry trade. We identified a trend characterized by the exploitation of economies of scale and competitiveness gains, but it did not find sufficient support to consolidate a process of de-primarization of exports. This description corresponds to the experience of the smallest economies of MERCOSUR, but also for Brazil, which is the most industrialized economy in the region. The use of break tests techniques allows us to support the idea that the conjunction of the volatility of the economies during the 1990s and the commodities boom during the 2000s may be useful to explain the setback. The first one would not have allowed the consolidation of a path of improvements in technological capabilities, and the second one strengthened the incentives to sustain natural resource-based production.

Our results and interpretation deserve attention in a future deepening of the analysis because they pose a theoretical problem. The analytical framework used does not consider the possibility of a setback in the industrialization process; it does not do so in a scheme with an absence of asymmetries, and, even less, in a scenario with a relatively more developed economy than that of the partners.

Following the ideas mentioned in the previous paragraph, the next steps towards understanding this topic should be based on different analyses, starting from breaks on univariate series and moving on a multivariate analysis, which includes possible determinant factors. Probably, the best alternative to measure their quantitative impact on the dynamics found in this paper would be a panel structure that models the heterogeneities. The main focus should be to understand the recent episodes of MERCOSUR. 


\section{REFERENCES}

Bekerman, M. and Dulcich, F. (2014). Dependencia comercial y patrones de especialización en un proceso de integración regional: el caso de $\mathrm{Ar}$ gentina y Brasil. Desarrollo Económico, 53(211). https://www.jstor.org/ stable/24368068

and Rikap, C. (2010). Integración regional y diversificación de exportaciones en el Mercosur: el caso de Argentina y Brasil. Revista de la CEPAL, 100. https://repositorio.cepal.org/handle/11362/11359

and Rodríguez, S. (2005). A Latin American perspective on trade policies. The International Trade Journal, 19(4). https://doi. org/10.1080/08853900500290798

Clemente, J., Montañes, A. and Reyes, M. (1998). Testing for a unit root in variables with a double change in the mean. Economics Letters, 59(2). https://doi.org/10.1016/S0165-1765(98)00052-4

Cooper, C. and Massell, B. (1965). Toward a general theory of custom unions for developing countries. The Journal of Political Economy, LXXIII (5). https://doi.org/10.1086/259070

Corbella, V. and Sarmento, K. (2017). La integración comercial y productiva de ALADI y su cambio estructural. EconomíaUNAM, 14(41). https://doi. org/10.1016/j.eunam.2017.06.005

Cordero, S. and González, G. (2018). Intensidad de la integración en el MERCOSUR: Complementariedad y sesgo geográfico no explicado [Paper presentation]. LIII Reunión Anual de la Asociación Argentina de Economía Política, La Plata.

De Cicco, J., Calá, C. and Berges, M. (2013). El comercio intraindustrial argentino: evolución y características en la convertibilidad y la postconvertibilidad. Faces, 19(40-41). http://nulan.mdp.edu.ar/id/eprint/1899

Delbianco, F. and Fioriti, A. (2014). Were financial flows in Latin America and the Caribbean shifted by their crises? International Journal of Finance and Economics, 20(2). https://doi.org/10.1002/ijfe.1503

and Fioriti, A. (2018). External cycles and commodities in Latin America and the Caribbean: A cointegration analysis with breaks. Lecturas de Economía, 88. https://doi.org/10.17533/udea.le.n88a02 and Fioriti, A. (2019). Dependence of Latin America external sector on commodities prices. A contemporaneity analysis using structural breaks. Económica, La Plata, LXIV(1). https://doi.org/10.24215/18521649e011 
Dickey, D. and Fuller, W. (1984). Testing for unit roots in seasonal time series. Journal of the American Statistical Associations, 79. https://doi.org/10. 1080/01621459.1984.10478057

Di John, J. (2009). From windfall to curse? oil and industrialization in Venezuela, 1920 to the present. The Pennsylvania State University Press.

Durán Lima, J. and Lo Turco, A. (2010). El comercio intrarregional en América Latina: patrón de especialización y potencial exportador. In M. Terra (coord.). Los impactos de la crisis internacional en América Latina: ¿hay margen para el diseño de politicas regionales? (pp. 91-150). Red MERCOSUR.

Fajnzylber, F. (1988). Competitividad internacional: evolución y lecciones. Revista de la CEPAL, 36. https://repositorio.cepal.org/handle/11362/11714

Frankel, J. and Rose, A. (1998). The endogeneity of the Optimum Currency Area Criteria. The Economic Journal, 108(449). https://doi.org/10. 1111/1468-0297.00327

Fullerton, T., Sawyer, Ch. and Sprinkle, R. (2011). Intra-industry trade in Latin America and the Caribbean. International Trade Journal, 25. https:// doi.org/10.1080/08853908.2011.532044

Gayá, R. and Michalczewsky, K. (2014). El comercio intrarregional sudamericano: patrón exportador y flujos intraindustriales. Nota técnica, IDBTN-583. BID, Instituto para la Integración de América Latina y el Caribe (INTAL).

González, G. (2009). Ganancias de competitividad: un enfoque agregado y de largo plazo. Análisis Económico, XXIV(57). https://www.redalyc.org/ pdf/413/41312227005.pdf

González, G. and Delbianco, F. (2021). Together or piled up. A new approach to Mercosur's lifetime. Revista de Economia Mundial, 57. http://dx.doi. org/10.33776/rem.v0i57.4646

Harberger, A. (1998). A vision of the growth process. American Economic Review, 88(1). https://www.jstor.org/stable/116816

Helpman, E. and Krugman, P. (1989). Trade policy and market structure, MIT Press.

Hernández, L. and Villalobos, C. (1997). El dinamismo de la renta petrolera y la industria manufacturera venezolana. Revista de Ciencias Sociales, III(2). https://dialnet.unirioja.es/servlet/articulo?codigo $=5719077$

International Monetary Fund (IMF) (2021). World Economic Outlook Database. https://www.imf.org/en/Publications/WEO/weo-database/2021/ April

Kim, Ch. and Lee, K. (2003). Regional trade arrangements and intra-industry trade: The case of Mercosur. Asian Journal of Latin America Studies, 16(1). 
https://citeseerx.ist.psu.edu/viewdoc/download?doi=10.1.1.516.976\&rep $=$ rep $1 \&$ type $=$ pdf

Krugman, P. (1980). Scale economies, product differentiation, and the pattern of trade. American Economic Review, 70(5). https://www.jstor.org/ stable/1805774

Lo Turco, A. (2008). Integración regional Sur-Sur y desarrollo industrial asimétrico: el caso Mercosur. In Red Mercosur (comp.). Asimetrías en el MERCOSUR ¿Impedimento para el crecimiento? (pp. 89-130). Red MERCOSUR.

Lucángeli, J. (2007). La especialización intraindustrial en MErcosur. Serie Macroeconomía del Desarrollo, 64. División de Desarrollo Económico, CEPAL.

Lumsdaine, R. and Papell, D. (1997). Multiple trend breaks and the unitroot hypothesis. Review of Economics and Statistics, 79(2). https://doi. org/10.1162/003465397556791

Moncarz, P., Olarreaga, M. and Vaillant, M. (2016). Regionalism as industrial policy: Evidence from Mercosur. Review of Development Economics, 20(1). https://doi.org/10.1111/rode. 12224

Perron, P. (1989). The great crash, the oil price shock, and the unit root hypothesis. Econometrica, 57(6). https://doi.org/10.2307/1913712

Perron, P. and Vogelsang, T. J. (1992). Testing for a unit root in a time series with a changing mean: Corrections and extensions. Journal of Business and Economic Statistics, 10(4). https://doi.org/10.1080/07350015.1992.1050 9923

Puga, D. and Venables, A. (1998). Trading arrangements and industrial development. The World Bank Economic Review, 12(2). https://doi.org/10.1093/ wber/12.2.221

Reig Lorenzi, N. and Puchet Anyul, M. (2019). El rol de Uruguay y México en la integración comercial del mercosur y del tLCAN: 1990-2016. Problemas del Desarrollo. Revista Latinoamericana de Economía, 50(198). https:// doi.org/10.22201/iiec.20078951e.2019.198.67471

Richards, D. (2011). Estancamiento económico y modelo exportador en Paraguay. Un análisis de series de tiempo. In F. Masi and D. Borda (eds.). Estado y Economía en Paraguay 1870-2010 (pp. 114-146). CADEP.

Sanguinetti, P., Siedschlag, I. and Volpe Martincus, C. (2009). The impact of South-South preferential trade agreements on industrial development: An empirical test. Inter-American Development Bank Working paper, INT/ INT-22. 
Swanson, W. (2012). Las exportaciones de productos industriales paraguayos en el marco del aCE 59. Informe obeI, Asunción.

Syrquin, M. and Chenery, H. (1989). Three decades of industrialization. The World Bank Economic Review, 3(2). https://doi.org/10.1093/wber/3.2.145

Venables, A. (2003). Winners and losers from regional integration agreements. The Economic Journal, 113(490). https://doi.org/10.1111/14680297.t01-1-00155

Volpe Martincus, C. (2003). Changing specialization patterns in MERCOSUR [Paper presentation]. Fifth Annual Meeting of ETSG, Madrid.

Yeats, A. (1998). Does Mercosur's trade performance raise concerns about the effects of regional trade arrangements? The World Bank Economic Review, 12(1). https://elibrary.worldbank.org/doi/abs/10.1596/1813-9450-1729

Zivot, E. and Andrews, D. (1992). Further evidence on the great crash, the oil price shock and the unit-root hypothesis. Journal of Business and Economic Statistics, 10(3). https://doi.org/10.1198/073500102753410372 